\title{
Detection of trends for extreme events of precipitation in the Metropolitan Region of Belo Horizonte through statistical methods
}

\section{Detecção de tendências para eventos extremos de precipitação na Região Metropolitana de Belo Horizonte a partir de métodos estatísticos}

\author{
Aline de Araújo Nunes ${ }^{1}$, Eber José de Andrade Pinto $^{2}$ and Márcio Benedito Baptista ${ }^{2}$ \\ ${ }^{1}$ Pontifícia Universidade Católica de Minas Gerais, Belo Horizonte, MG, Brazil \\ ${ }^{2}$ Universidade Federal de Minas Gerais, Belo Horizonte, MG, Brazil \\ E-mails: alinedearaujonunes@gmail.com (AAN), eber@ehr.ufmg.br(EJAP), marcio.baptista@ehr.ufmg.br (MBB)
}

Received: August 20, 2017 - Revised: December 08, 2017 - Accepted: January 12, 2018

\begin{abstract}
Extreme weather events have emerged as one of the main manifestations of climate change, being that the mitigation of the elapsed impacts demand studies of the magnitude and frequency of their occurrence. This study aims to identify the trends of extreme precipitation events in the Metropolitan Region of Belo Horizonte, especially concerning their frequency. The trends of precipitation were studied with especial regard to the indices set by ETCCDMI (Expert Team on Climate Change Detection Monitoring and Indices), including time series of annual number of rainy days above a certain threshold recorded at fourteen rainfall gauging stations. One stage of this study consisted in surveying the flood occurrence in the area, besides analyzing the precipitation data corresponding to date of flood occurrences, in order to establish a threshold value beyond which an event would entail potential impacts. No regional index pattern could be set based on such results, although the rainfall station located in the city of Belo Horizonte reported a statistically significant increase in daily precipitation events above $10,20,30$ and $40 \mathrm{~mm}$, in maximum precipitation recorded over five consecutive days, in daily intensity, and in total annual precipitation. Abrupt changes in rainfall series were also recorded. The results have indicated that the city may be potentially impacted by extreme rainfall increase, probably associated to changes in temperatures on regional and local scales.
\end{abstract}

Keywords: rainstorm events; climate changes; non-stationarity.

\section{RESUMO}

Eventos climáticos extremos são considerados uma das principais manifestações de mudança climática, sendo que a minimização dos impactos decorrentes passa pelo estudo da magnitude e frequência de suas ocorrências. Neste sentido, a presente pesquisa busca identificar tendências em eventos extremos de precipitação na Região Metropolitana de Belo Horizonte, à luz da crescente preocupação com o aumento de sua ocorrência na região. As tendências da precipitação foram estudadas, principalmente, por meio dos índices estabelecidos pela ETCCDMI, incluindo séries temporais do número anual de dias chuvosos acima de um certo limiar estabelecido, considerando quatorze estações pluviométricas. A fim de estimar o valor de precipitação limiar, que acarretaria potenciais impactos, foi realizada uma busca de alagamentos ocorridos na região, para que estes fossem associados aos dados de precipitação nos dias de sua ocorrência. A análise efetuada não permitiu a detecção de um padrão regional nos índices analisados, no entanto, a estação localizada em Belo Horizonte apresentou aumento dos eventos de precipitação diária iguais ou superiores a 10, 20 , 30 e 40 mm, na precipitação acumulada em cinco dias consecutivos, na intensidade diária e no total anual precipitado. Foram também registradas mudanças abruptas nas séries de precipitação. Os resultados indicaram que Belo Horizonte pode ser impactada pelo aumento de chuvas extremas, fato que pode estar associado a mudanças identificadas nas séries de temperatura.

Palavras-chave: chuvas extremas; mudanças climáticas; não estacionariedade. 


\section{INTRODUCTION}

Extreme climatic events have been one of the main consequences of climate changes in many places around the world. Extreme events have usually been characterized by atypically high or low values recorded within an observation time frame (IPCC, 2012).

The global warming, the increase in the temperature averages around the planet, may cause higher evaporation rates that raise the amounts of water vapor released into the atmosphere, and speed up the global hydrologic cycle (XU; ZHANG; RUAN, 2006). Thus, one of the consequences of the global warming would be the increase in the magnitude and frequency of extreme precipitation occurrences brought forth by the raise of atmospheric humidity and/or convective activities on a large scale (SEN ROY; BALLING JR, 2004).

Such assumption has also been validated by considering the increase trend in the specific humidity all over the world that's been observed since 1970 (WILLETT et al., 2008), followed by Alexander et al. (2006) who reported a significant increase in extreme precipitation events on a global scale.

On the other hand, Shang et al. (2011), based on an increasing concern about whether there is a significant trend in extreme precipitation associated with climate changes in Ethiopia, performed a trend analysis with daily time series of precipitation records at Debre Markos in the Northwestern Highlands of Ethiopia, and found no strong evidence of increasing trend in extreme precipitation at this location. In addition, studies perfomed in Brazil (SALVIANO; GROPPO; PELLEGRINO, 2016) and India (KRISHNAKUMAR; PRASADA RAO; GOPAKUMAR, 2009) showed contrasted results (positive, negative and insignificant trends) according to the region.

Parallel to these climatic changes, many regions have also been rapidly urbanizing (KISHTAWAL et al., 2009). There is increasing evidence that urbanization can have a significant feedback on the spatiotemporal patterns of precipitation (DANTAS; SANTOS; OLINDA, 2015; SOUZA; NASCIMENTO; ALVALÁ, 2015).

Cotton and Pielke (2007) cite many studies on how the urbanization changes precipitation patterns as a result of mesoscale circulations and through changes in the potential convective energy available. In addition, the recent researches continue to show evidence on how the increase in the surface temperature (FERREIRA; BATISTA; VIANNA, 2015; ARAÚJO; SILVA; MACHADO, 2016) and precipitation anomalies (RAIMUNDO; SANSIGOLO; MOLION, 2014) may be linked to urban environments.

According to Sigrist, Künsch and Stahel (2012) precipitation is a very complex phenomenon that varies in space and time, and there are many efforts to model its nonstationarity. Tsonis (1996) analyzed low-frequency variability of global precipitation over the past century and found that the fluctuations about the global mean have increased significantly, while the mean values have not changed. Thus, in this example, it is implied that the global precipitation process was nonstationary in the past century. Such a change in regime highlights a destruction of the stationary behavior of the system, even though the cause for this change has not been identified. Most theories of time series prediction assume that a predicted process is stationary, but in some instances, weather and climate time series are shown to be nonstationary (YANG et al., 2010).

Studies were carry out in different places of the world in order to identify changes in hydrological time series, especially to try out the application of statistical test to detect trends (e.g. BLANCHET; MOLINIÉ; TOUATI, 2016; SANCHES; VERDUM; FISCH, 2013; and others). The investigation of possible climate changes is primary focus of such studies (MADSEN et al., 2014).

The main statistical tests used in studies to estimate the significance of gradual changes in the series of hydrological data are the nonparametric tests Mann-Kendall, Spearman (e.g. MOREIRA; NAGHETTINI, 2016; SILVEIRA; FERNANDES; SILVA, 2017; SANTOS et al., 2016) and Seasonal Kendall, and the parametric test of linear regression (e.g. WANDERLEY et al., 2013), which is mean to check whether there is a linear trend in the relationship between time and the variable of interest. Other important trials performed to detect changes in hydrological data related to the series have been meant to detect abrupt changes by the analysis of the significance of the change in the mean or median of the sample compared to the known and/or unknown series points.

Van den Bessalar, Klen-Tank and Buishand (2013) analyzed the trends of extreme precipitation events in Europe by applying the linear regression test to one-day rainfall index - maximum monthly rainfall event in one day - and the 5-day rainfall index - maximum monthly precipitation in 5 consecutive days - record at 478 rainfall stations over the period between 1951 and 2010. In Northern Europe, there was an increase in the extreme precipitation in the fall, winter and spring, while in Southern Europe there was only a small increase in extreme precipitation in all seasons.

Villarini et al. (2011) studied extreme precipitation events occurred in the Midwest United States from annual maximum daily rainfall time series of 221 rain gages with a record of at least 75 years. The occurrence of slowly varying changes was analyzed by Mann-Kendall and Spearman tests, at the 5\% significance level, that have found an increasing trend at 19 stations.

In Brazil, a study carried out in the Metropolitan Region of Belo Horizonte (ALEXANDRE; BAPTISTA; NAGHETTINI, 2010) have demonstrated the likelihood of precipitation increase over the dry season, and precipitation decrease over the rainy season, although the total yearly precipitation has not shown any evidence of changes in their series.

Queiroz (2013) studied trends of annual maximum daily precipitation series in central area of the state of Minas Gerais, in Brazil, based on the precipitation indices recommended by CLIVAR (Climate and Ocean: Variability, Predictability and Change), which is one of the four core projects of the World Climate Research Programme, that may be applied to detect climate changes. Precipitation indices of heavy precipitation days (R99p), number of days with precipitations above $30 \mathrm{~mm}$ (R30mm), maximum precipitation amount in five days (Rx5day), and Simple Day Intensity Index (SDII) showed predominantly positive trends.

Many studies have reported significant changes in local and regional climate characteristics, and furthermore, how environmental changes have affected the weather. Although atmosphere controls of each scale differ, many scale levels are interconnected, and may interfere with each other. For example, regional climate changes 
may occur after changes in the atmosphere controls that organize that scale such as action centers and associated atmosphere systems and geographic attributes. At a local level, the scope includes places where the anthropic action is among the main organization factors, and cause innumerous atmospheric changes (NUNES, 2003).

Also at a local level, the development and growing of urban centers have brought forth a peculiar phenomenon called 'urban heat island', characterized by temperature raise in urban areas compared to their surrounding areas, and the increase in the turbulence of condensation nucleus in the atmosphere, which favors the occurrence of rainstorms (SHAW; SHARMA, 2011). It seems that such phenomenon may cause the same mentioned effects, and increase the magnitude and frequency of extreme precipitation events.

Considering the significant concentration of people in urban centers, the issue of vulnerability of cities regarding possible non-stationarity of hydro-climatological conditions must be checked for the potential induction of rainstorm occurrences caused by the urban concentration, and as well for possible global climate changes. Therefore, it's of all importance to search for evidences of such trends, quantify them, and develop tools and strategies to improve the resilience of urban centers.

In this context, it is important to know the evolution of the magnitude and frequency of extreme precipitation events in the city of Belo Horizonte, which is very sensitive to the problem of flood due to its topography, urbanization pattern and intense land use. This work aims at detecting the trends of rainstorm series, based on extreme precipitation series with potential to cause flood events around the area by performing statistical tests and applying methods and indices set by WMO (2009) - World Meteorological Organization. The temperature behavior in and around the city has also been studied in order to evaluate the 'urban heat island' effect.

\section{MATERIAL AND METHODS}

\section{Characterization of the study area}

The Metropolitan Region of Belo Horizonte (MRBH) is located between the latitudes $19^{\circ} 00^{\prime}$ and $20^{\circ} 30^{\prime} \mathrm{S}$ and longitudes $43^{\circ} 15^{\prime}$ and $44^{\circ} 45^{\prime} \mathrm{W}$, in the central area of the state of Minas Gerais, in Southeast region of Brazil (Figure 1), on the basin of the rivers 'das Velhas' and 'Paraopeba', which are tributaries of the 'São Francisco' river.

The region comprises the third largest urban population in Brazil, with 5.8 million inhabitants (2.5 million inhabitants in the city of Belo Horizonte), according to 2010 census (IBGE, 2010), spread over an area of $9,468 \mathrm{~km}^{2}$ with 34 municipalities. The population of Belo Horizonte has been significantly growing in the last 50 years, as shown in Figure 2. Such growth has particularly impacted the environment quality, noticeably regarding the average annual temperature that raised $1.5^{\circ} \mathrm{C}$ over the last 80 years, while there was a considerable increase in the occurrence of floods (BAPTISTA; NASCIMENTO; BARRAUD, 2011).

The MRBH is inserted in area with climate types classified by Köppen as Aw, Cwa and Cwb (humid climates, with dry winter and wet summer). In fact, it may be considered a rainy area as its average annual precipitation is about $1,500 \mathrm{~mm}$, highly concentrated in the season that goes from October to March, with nearly $90 \%$ of the total annual. The rainfalls in the area are mostly caused by the passage of fronts and the South Atlantic Convergence Zone.

\section{Trend analysis for time series of temperatures}

The "urban heat island" phenomenon, frequent in large urbanized areas, is characterized by higher temperatures in the city than their surrounding areas. In the city of Belo Horizonte it was evidenced by some researches (MAGALHÃES FILHO; ABREU, 2015; and others) and in this paper, the temperature data were also analyzed.

The database used, corresponding to the climatological stations of Belo Horizonte - MG (83587) and Florestal - MG (83581), located in the cities with the same names (Figure 1), was obtained from INMET (National Institute of Meteorology). The data collection periods were from 1961 to 2016 at Belo Horizonte station, and from 1961 to 2001 at Florestal station.

To verify any possible change in the temperature patterns, the gradual change test Mann-Kendall was applied, at the significance level of $5 \%$, to the series of mean, mean maximum and mean minimum temperatures of both stations. The results obtained were then compared, considering that Belo Horizonte station is located at an altitude of 915 meters and Florestal station at 760 meters. In contrast of Belo Horizonte, Florestal is a small city, in principle not significantly influenced by urbanization or industrialization impacts.

\section{Data collection and analysis about rainfall in the MRBH}

The daily precipitation data of $\mathrm{MRBH}$ were selected from the georeferenced database provided by the Brazilian National Water Agency (ANA), and the available hydrologic series on hydrologic information system of the agency, named 'Hidroweb'. The parameters that guided such selection were series comprising at least 50 years of records, searching for a uniformity of spatial distribution of rainfall stations in the MRBH.

Fourteen (14) rain gauges were selected and the positioning map of the stations is presented on Figure 3. Due to the requirement to keep records with at least 50 years of data, it was not possible to obtain a homogeneous coverage of rainfall stations in the analyzed region, as can also be noticed in Figure 3. Nevertheless, it has been assumed that the selected stations may be enough to characterize the rainfall pattern of the metropolitan area of Belo Horizonte. The precipitation series were validated by the classical double-mass analysis method.

Data collection and analysis about floods around the MRBH - Definition of the threshold of precipitation which potentially generates floods

According to the National Secretariat of Civil Defense, in publication of Joint Ordinance No. 148, of December 18 (BRASIL, 2013), urban flood can be defined as an "Extrapolation of the outflow capacity of urban draining systems and the consequent 


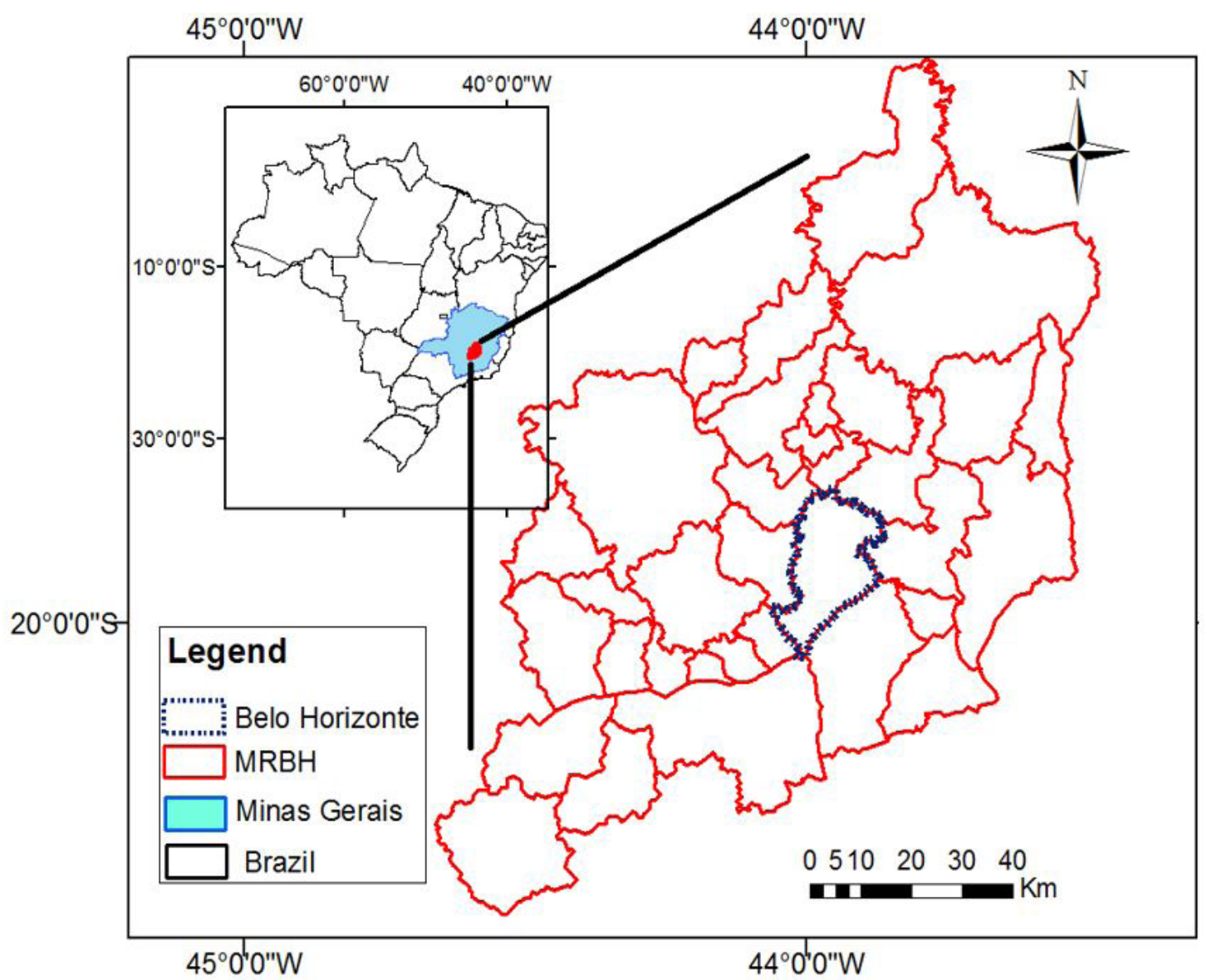

Figure 1. Location of the MRBH in Brazil.



Figure 2. Growth of the Population of Belo Horizonte from 1900 to 2010. (Source: BAPTISTA; NASCIMENTO; BARRAUD, 2011; IBGE, 2010).

inundation of lowland areas overflowing thoroughfares, sidewalks or other urban infrastructures due to heavy precipitations". Based on such definition, flood events that occurred over the last 35 years in the city of Belo Horizonte were surveyed in order to correlate the date of such events to the records of rainfalls in the area on the same days. So, warning rainfall events were defined in this work as precipitations able to cause floods in the area.

The flood events survey covers the time frame from 1979 to 2014 according to the minimum 30-year period required by World Meteorological Organization for a climatic characterization of an area (WMO, 2007). The occurrence of such events was collected from the database of the technical department of

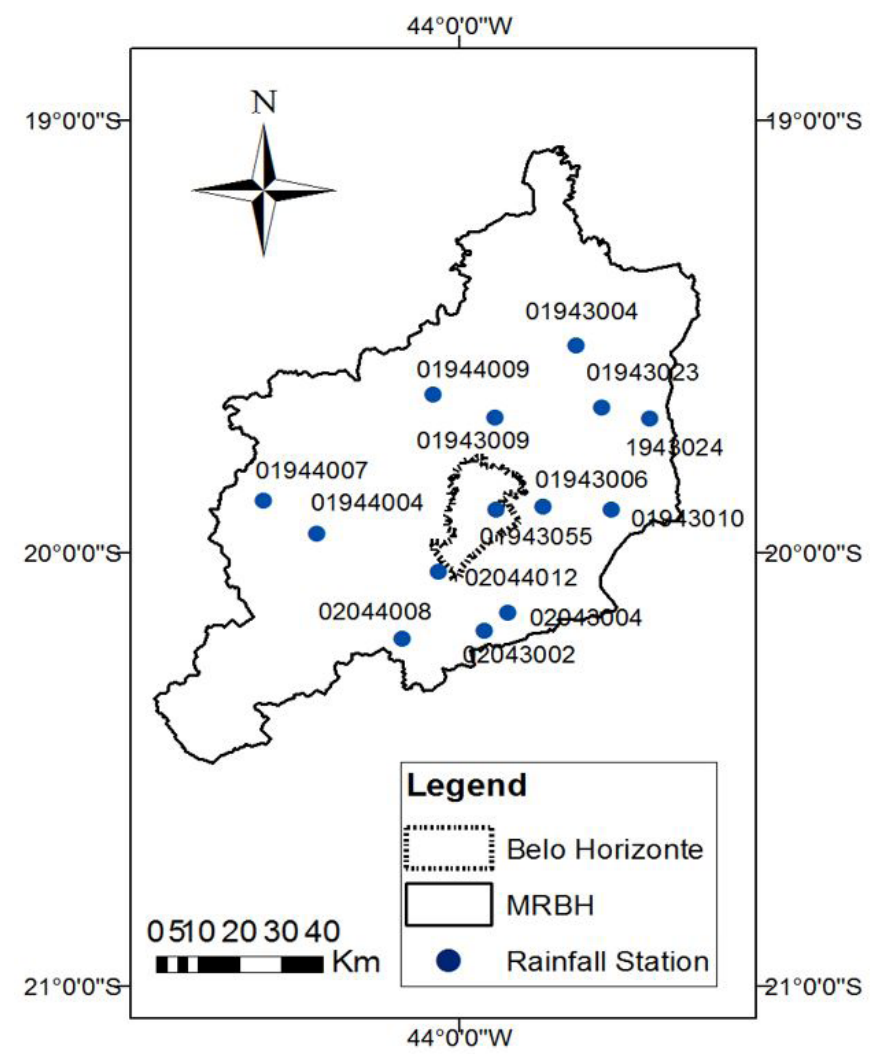

Figure 3. Location of rainfall gauging stations selected in MRBH. 
the City Hall (SUDECAP), consolidated by news published in Brazilian newspapers such as 'Estado de Minas' and 'Folha de São Paulo'. The consolidation of the data by different sources was necessary because records of long-term flood events were not available; such type of data is not object of systematic collection in Belo Horizonte.

Regarding the stations located closer to, or in Belo Horizonte (01943055 and 02044012), their time series were analyzed according to the dates corresponding to flood events; the precipitation depths on those days were selected. Once obtained these daily precipitation depths, the median of these values was calculated to set a threshold value that would indicate a rainfall that could cause flood in the city, i.e. an extreme rainfall.

Considering that it was not possible to obtain the duration of the precipitations and, consequently, to estimate the average intensity of the events and to identify if these floods were a consequence of drainage problems (obstructed storm drains and drainage galleries, etc), it was used a measure of central tendency that is less susceptible to the presence of outliers, i.e., the sample median, as an indicator of daily rainfall that can cause flood problems. The median's resistance to the effect of a presence of outlying observations is an important property (HELSEL; HIRSCH, 2002).

It is worth mentioning that the threshold value to be established is only a rainfall indication with the potential to cause floods in the metropolitan region of Belo Horizonte. In fact, several factors may influence the behavior of the basin during a rainstorm event such as, for example, initial soil moisture, land use and occupation, drainage system maintenance and actual conditions, among others.

\section{Analysis of the time series of precipitation indices}

In that stage, precipitation indices were applied according to the definition of ETCCDMI, the Expert Team on Climate Change Detection Monitoring and Indices (PETERSON et al., 2001). The precipitation indices are shown in Table 1.

For each rainfall gauging station, time series of indices by hydrological year were prepared. The trends of the time series

Table 1. Precipitation indices.

\begin{tabular}{ccc}
\hline ID & Index name & Units \\
\hline CDD & Consecutive dry days & Days \\
CWD & Consecutive wet days & Days \\
SDII & Daily intensity index & $\mathrm{mm} /$ day \\
R10 & Annual number of rainy days above $10 \mathrm{~mm}$ & Days \\
R20 & Annual number of rainy days above $20 \mathrm{~mm}$ & Days \\
R30 & Annual number of rainy days above $30 \mathrm{~mm}$ & Days \\
Rnn & Annual number of rainy days above a & Days \\
& threshold of nn mm & $\mathrm{mm}$ \\
Rx1DAY & Maximum monthly precipitation on a day & $\mathrm{mm}$ \\
Rx5DAY & Maximum monthly precipitation over 5 & $\mathrm{mm}$ \\
& consecutive days & $\mathrm{mm}$ \\
R95P & Very wet days & $\mathrm{mm}$ \\
R99P & Extremely wet days & $\mathrm{mm}$ \\
PRCPTOT & Total annual wet days & \\
\hline
\end{tabular}

Source: WMO (2009). were evaluated, according to Kundzewicz and Robson (2004), by the gradual changes test Mann-Kendall, and by the abrupt changes tests, described in Chiew and Siriwardena (2005), Distribution Free CUSUM (detect the average change in two periods) and Rank Sum (detect the median change in two periods), being all them nonparametric tests. The significance level considered in the tests was $5 \%$.

\section{RESULTS AND DISCUSSION}

\section{Analysis of the time series of temperatures}

In Figure 4 is shown the evolution of the mean, mean maximum and mean minimum temperatures in climatological stations from Belo Horizonte and Florestal. It is possible to observe a positive trend in the data of mean and minimum annual temperature for the two stations, and an apparent change in temperature patterns from the 80's.

An important fact to observe is a positive trend in the annual maximum temperatures for Florestal station, which is not observed in the station located in Belo Horizonte. Apparently, the increase of the mean temperature is justified, in the city of Belo Horizonte, by a marked increase of the minimum temperatures, unlike the

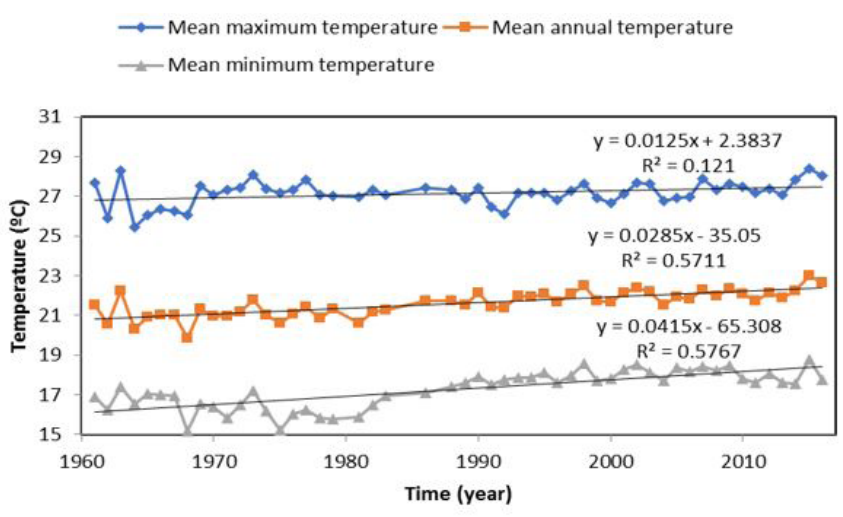

(a)

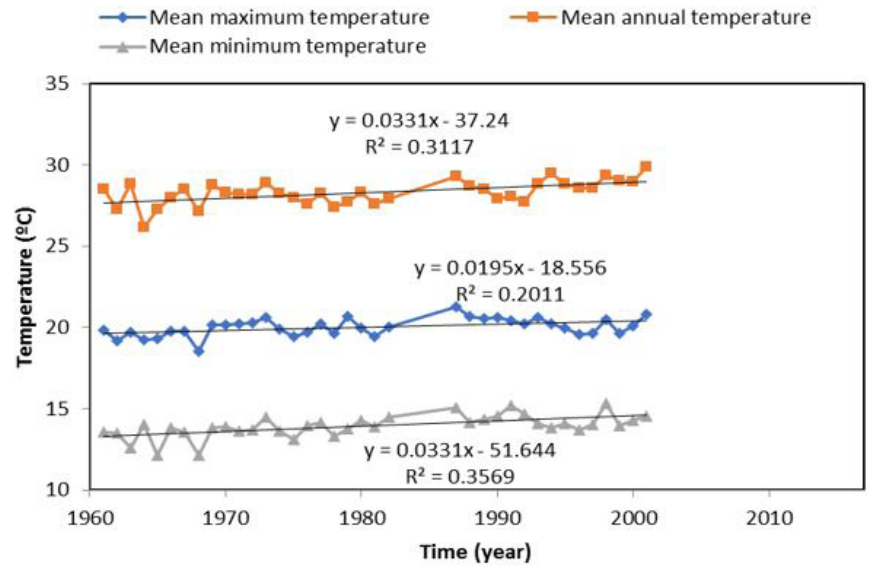

(b)

Figure 4. Mean, mean maximum and mean minimum temperatures - Stations of Belo Horizonte (a) and Florestal (b). 
city of Florestal that presents increase of the three temperatures, although it is possible to note that the series are shorter.

It is noteworthy that, although an increase in annual maximum temperatures for the city of Florestal has been observed, the mean and minimum temperatures for the city of Belo Horizonte are considerably higher, besides also presents a positive trend over the years (an increase of about $1.0^{\circ} \mathrm{C}$ in mean annual temperature for Belo Horizonte, while Florestal station indicates an increase of approximately $0.4{ }^{\circ} \mathrm{C}$ - considering a common period of 1961-2001). In addition, although the two cities in $\mathrm{MRBH}$ are in the same climatic region, approximately with the same latitudes, Belo Horizonte station is located about a $165 \mathrm{~m}$ higher than Florestal.

Similar results were found in studies carried out for the cities of Campinas (BLAIN; PICOLI; LULU, 2009) and Petrolina and Juazeiro (LEITÃO et al., 2011), which detected a higher increase in minimum temperature for the urban center when compared to nearby areas, less affected by the effects of urbanization. These authors relate the elevation of the minimum temperature with local factors, for example, to the urban heat island, excluding the hypothesis of large scale factors, such as global warming.

In order to verify the significance of the observed changes, the trend analysis was performed using the Mann-Kendall test, at the significance level of $5 \%$, and the results are presented in Table 2 (S+ stands for significant positive trend, while NS stands for non-significant trend).

It is observed that the questions pointed out in the visual analysis of the temperature data were confirmed. Temperatures indicate, in general, positive trends, except for the annual maximum temperature data for the city of Belo Horizonte.

\section{Analysis of floods and rainfall}

The investigation aimed to analyze flood events that took place from 1979 to 2014 in the city of Belo Horizonte reported 104 flood events that have been sorted in chronological order. The days of flood occurrence were analyzed in the time series of daily precipitation recorded at the rainfall stations 01943055 and 02044012 in order to find any rainfall indication that may have contributed to flood events in the city.

Table 3 presents the daily heights of precipitation observed in days of occurrence of such events. It is observed some flood dates without corresponding rainfall data because the analysis was carried out by coverage area of the station, i.e. if there is not flood registered in specific area, no rainfall data was analyzed.

The descriptive characteristics of the selected samples, considering the precipitation heights of both stations, were obtained (first quartile - Q1, second quartile - Q2; third quartile

Table 2. Trend analysis for temperature performed by MannKendall test, at the significance level of $5 \%$.

\begin{tabular}{cccc} 
Station & $\begin{array}{c}\text { Mean } \\
\text { Maximum } \\
\text { Temperature }\end{array}$ & $\begin{array}{c}\text { Mean } \\
\text { Annual } \\
\text { Temperature }\end{array}$ & $\begin{array}{c}\text { Mean } \\
\text { Minimum } \\
\text { Temperature }\end{array}$ \\
\hline Belo Horizonte & $\mathrm{NS}$ & $\mathrm{S}+$ & $\mathrm{S}+$ \\
Florestal & $\mathrm{S}+$ & $\mathrm{S}+$ & $\mathrm{S}+$ \\
\hline
\end{tabular}

- Q3; and maximum and minimum magnitude of precipitation) and are shown in Table 4.

Considering the preliminary analysis of the data, it is observed that the minimum and maximum precipitation heights (Min and Max) represent values that could, in principle, be characterized as outliers, since they represent atypical points when compared to the other recorded precipitation heights. However, when analyzing other rain gauges of the $\mathrm{MRBH}$, it was possible to infer that these events were observed with similar magnitudes in other areas of the region. In addition, considering the notorious urbanization in Belo Horizonte city, rainfall with low magnitudes, such as the minimum precipitation height recorded (Min), when associated with short durations may be responsible for floods.

Considering the impossibility of obtain the duration of the precipitations and, consequently, to estimate the average intensity of the events, it was obtained the median of the daily rainfall, a measure of central tendency that is less susceptible to the presence of atypical values, allowing to set a threshold of $40 \mathrm{~mm}$. To check the pertinence of the adopted reference value, studies applied to Belo Horizonte and other places were analyzed.

The classification of precipitation in Belo Horizonte, for the use of flood warnings, shows that rains in the range of 30 to $50 \mathrm{~mm}$, according to the recording of rain gauges (daily precipitation) located in the city, are considered heavy rains, and greater than $50 \mathrm{~mm}$, extremely heavy rains (REIS et al., 2004). It was also calculated the percentile of the daily precipitation in rainy days (above $0.1 \mathrm{~mm}$ ) at the two gage stations equivalent to the threshold of $40 \mathrm{~mm}$, being obtained a percentile of 92.5 ; the survey of some thresholds taken for other studies indicated percentiles of 85 (XAVIER, 2001; ANANIAS et al., 2010), and 95, and daily totals equivalent to values ranging from 42 and $65 \mathrm{~mm}$ (MOURA; ESCOBAR; ANDRADE, 2013) in cities with the level of urbanization similar to Belo Horizonte.

\section{Analysis of the time series of precipitation indices}

The time series of precipitation indices were checked, firstly, by the gradual trend test Mann-Kendall, considering the significance level of $5 \%$. Figure 5 shows the spatial distribution of the trends by precipitation index, considering that $\mathrm{S}+$ stands for significant positive trend, while $\mathrm{S}_{-}$stands for significant negative trend.

The results shown indicate that R10, R20, R40, Rx1DAY, Rx5DAY, R95P and PRCPTOT indices presented significant trends at most in three rain gauges, which suggested that there is no regional trend to such indices in MRBH. On the other hand, when a statistic significance was found it was noticed that such indices preponderantly indicate positive trends, and possible changes in the rainfall pattern may indicate an increase in the relevant indices related to urban drainage systems, such as very wet days (R95P), the maximum monthly precipitation in one and five consecutive days, and the number of rainy days with precipitation above 10, 20, 30 and $40 \mathrm{~mm}$.

R30 index showed significant positive trend at four stations of the MRBH. It's been noticed that the stations which have shown an increasing trend in R30 index are located within the East side of the MRBH, which indicates an increase in the number 
Table 3. Daily precipitation heights recorded in flood days.

\begin{tabular}{|c|c|c|c|c|c|c|c|c|c|c|c|}
\hline \multirow{2}{*}{$\begin{array}{c}\text { Date of } \\
\text { flood } \\
\mathrm{dd} / \mathrm{mm} / \\
\text { уууу }\end{array}$} & \multicolumn{2}{|c|}{$\mathbf{P}(\mathrm{mm})$} & \multirow{2}{*}{$\begin{array}{c}\text { Date of } \\
\text { flood } \\
\text { dd/mm/ } \\
\text { ууyу }\end{array}$} & \multicolumn{2}{|c|}{$\mathbf{P}(\mathrm{mm})$} & \multirow{2}{*}{$\begin{array}{c}\text { Date of } \\
\text { flood } \\
\text { dd/mm/ } \\
\text { yуyy }\end{array}$} & \multicolumn{2}{|c|}{$\mathbf{P}(\mathrm{mm})$} & \multirow{2}{*}{$\begin{array}{c}\text { Date of } \\
\text { flood } \\
\text { dd/mm/ } \\
\text { yуyy }\end{array}$} & \multicolumn{2}{|c|}{$\mathbf{P}(\mathrm{mm})$} \\
\hline & 01943055 & 02044012 & & 01943055 & 02044012 & & 01943055 & 02044012 & & 01943055 & 02044012 \\
\hline $21 / 10 / 2014$ & 19 & 60 & $15 / 01 / 2010$ & 61 & 23.5 & $08 / 02 / 1989$ & 27.9 & 12.2 & $11 / 02 / 1983$ & 51.8 & 78.6 \\
\hline $02 / 04 / 2014$ & 37 & - & $07 / 10 / 2009$ & 18.9 & 33.7 & $30 / 09 / 88$ & 68 & 61.7 & $21 / 01 / 83$ & 51 & 53.5 \\
\hline $03 / 04 / 2014$ & 48.8 & - & $22 / 01 / 2009$ & 35.9 & 9.9 & $17 / 03 / 88$ & 50 & 30.5 & $04 / 01 / 1983$ & 11.2 & 18.6 \\
\hline $18 / 01 / 2014$ & - & - & $18 / 12 / 2008$ & 21.8 & 47.3 & $08 / 02 / 1988$ & 63.6 & 59.4 & $02 / 01 / 1983$ & 32.4 & 63.2 \\
\hline $22 / 12 / 2013$ & 29 & - & $15 / 12 / 2008$ & 67.7 & 31.2 & $14 / 12 / 87$ & 40.2 & 61.2 & $26 / 01 / 1982$ & 13 & 14.1 \\
\hline $12 / 12 / 2013$ & 63.1 & 75.4 & $17 / 09 / 2008$ & - & - & $09 / 12 / 1987$ & 89.2 & 47.1 & $24 / 01 / 1982$ & 35.6 & 52.2 \\
\hline $09 / 04 / 2013$ & - & 24.8 & $26 / 11 / 2007$ & - & 21.3 & $06 / 12 / 1987$ & 28.6 & 30 & $03 / 01 / 1982$ & 112.6 & 81.6 \\
\hline $07 / 01 / 2013$ & 60.8 & 18.5 & $30 / 11 / 2006$ & 156.3 & 36.6 & $11 / 03 / 1987$ & 37.8 & 65.7 & $27 / 11 / 1981$ & 11.8 & 17.7 \\
\hline $29 / 12 / 2012$ & - & 13.8 & $29 / 11 / 2006$ & 29.4 & 40.3 & 08/03/1987 & 5.4 & 18.6 & $14 / 11 / 1981$ & 53.3 & 50.8 \\
\hline $15 / 11 / 2012$ & 14.1 & 19.6 & $04 / 12 / 2003$ & 57.2 & 24.9 & $27 / 12 / 86$ & 19.8 & 45.2 & $13 / 11 / 1981$ & 25.6 & 32.6 \\
\hline $07 / 11 / 2012$ & 10.5 & 9.7 & $16 / 01 / 2003$ & 83.4 & 206.1 & $26 / 12 / 86$ & 37.6 & 24.8 & $11 / 11 / 1981$ & 95 & 71 \\
\hline $05 / 11 / 2012$ & 60.9 & 31.9 & $18 / 12 / 2000$ & 158.8 & 126 & $12 / 12 / 1986$ & 44.5 & 14 & $10 / 11 / 1981$ & 40.7 & 34.2 \\
\hline $15 / 03 / 2012$ & 29.7 & 14 & $28 / 01 / 2000$ & 77.2 & 124.5 & $11 / 01 / 1986$ & 28.3 & 34.8 & $13 / 01 / 1981$ & 62.3 & 68.4 \\
\hline $30 / 01 / 2012$ & 56.6 & 55.7 & 24/12/1999 & 80.2 & 60.8 & $10 / 01 / 1986$ & 35.1 & - & $12 / 01 / 1981$ & 35.8 & 55.8 \\
\hline $28 / 01 / 2012$ & 30.6 & 46.9 & $30 / 10 / 1998$ & 10.6 & 35.9 & $09 / 01 / 1986$ & 11.3 & 52.6 & $10 / 01 / 1981$ & 35 & 79.2 \\
\hline $02 / 01 / 2012$ & 74.4 & 88 & 04/01/1997 & 147.4 & 116.9 & $18 / 03 / 85$ & 99.7 & 90.2 & $10 / 12 / 1980$ & 24.2 & 35.2 \\
\hline $30 / 12 / 2011$ & 10 & 8.4 & $14 / 12 / 1995$ & 138.7 & 196.2 & $26 / 02 / 85$ & 92.6 & 61 & $07 / 12 / 1980$ & 22 & 34.9 \\
\hline $29 / 12 / 2011$ & 9.9 & 25 & $09 / 10 / 1995$ & 72.4 & 46.9 & $29 / 01 / 85$ & 60 & 19.8 & $05 / 12 / 1980$ & - & 10.2 \\
\hline $27 / 12 / 2011$ & 48.6 & 39.5 & 24/01/1992 & 72.6 & 71.6 & $26 / 01 / 85$ & 117.2 & 52.6 & $03 / 12 / 1980$ & 20.8 & 44.4 \\
\hline $15 / 12 / 2011$ & 91.4 & 51.5 & 28/01/1991 & 46.9 & 129.4 & $07 / 01 / 1985$ & 17.8 & 12.4 & $25 / 11 / 80$ & 55.4 & 21.1 \\
\hline $11 / 12 / 2011$ & 18.6 & 24.3 & $28 / 11 / 1990$ & 54.8 & 17.2 & $17 / 12 / 84$ & 63 & 62.2 & $29 / 01 / 1980$ & 22.6 & 28.4 \\
\hline $28 / 02 / 2011$ & 39.9 & 23.5 & $16 / 12 / 89$ & 76.4 & 51.2 & $16 / 12 / 84$ & 134.3 & 92.2 & $02 / 01 / 1980$ & 38.5 & 33.8 \\
\hline $15 / 01 / 2011$ & - & - & $14 / 12 / 89$ & 38.7 & 65.6 & $04 / 12 / 1984$ & 70 & 80 & $28 / 12 / 79$ & 50.2 & 26 \\
\hline $06 / 12 / 2010$ & 60.4 & 84.9 & $13 / 12 / 89$ & 78 & 85.4 & $10 / 12 / 1983$ & 49.2 & 77.4 & $27 / 12 / 79$ & 54.9 & 10.9 \\
\hline $23 / 11 / 2010$ & 75.5 & 40.8 & 06/11/1989 & 20 & - & $07 / 12 / 1983$ & 40.7 & 44 & $08 / 02 / 1979$ & 35.6 & 9 \\
\hline $03 / 03 / 2010$ & 30.6 & 14.3 & $15 / 03 / 89$ & 41.2 & 32 & $01 / 03 / 1983$ & 35.6 & - & 04/02/1979 & - & - \\
\hline
\end{tabular}

Table 4. Descriptive characteristics of the time series of daily precipitation heights recorded in flood days.

\begin{tabular}{lcc}
\multicolumn{1}{c}{$\begin{array}{c}\text { Sample characteristics } \\
(\mathbf{m m})\end{array}$} & $\begin{array}{c}\text { Station } \\
\mathbf{0 1 9 4 3 0 5 5}\end{array}$ & $\begin{array}{c}\text { Station } \\
\mathbf{0 2 0 4 4 0 1 2}\end{array}$ \\
\hline Min (Minimum precipitation) & 5,4 & 8,4 \\
1Q (First quartile) & 28,5 & 23,7 \\
2Q (Second quartile) & 42,9 & 40,6 \\
3Q (Third quartile) & 64,6 & 62,1 \\
Max (Maximum precipitation) & 158,8 & 206,1 \\
\hline
\end{tabular}

of rainy days over the year above $30 \mathrm{~mm}$ in this area. It's worth mentioning that the stations showing significant positive trend in R20 and R40 indices, also showed significant trend in R30 index, which reinforced the assumption of changes in the precipitation pattern in the East side of area.

Considering the spatial distribution of the CWD index, it can be seen that four (4) stations reported significant negative trend, and indicated a decrease in the number of consecutive rainy days in the Northern and South-west areas. By also analyzing Figure 5, it's noticed that CDD index indicates a prevailing and concentrated positive trend in the Northern and Central areas, which indicates an increase in the number of consecutive dry days within these areas. Such findings indicated a trend to accumulate precipitations on a shorter time scale in the Northern and Central areas, which's been confirmed by the SDII index with positive significance at the stations 01943004 and 01943055.

Taking into account the localization of the station 01943055 , in the city of Belo Horizonte, it is important to underline such results. The identified trends indicate the increase in relevant indices for urban drainage systems, i.e., CDD, SDII, R10, R20, R30, R40, Rx5DAY and PRCPTOT (the graphs with the temporal variation of the precipitation indices are shown in Figure 6), being also the station with the highest number of indices which presented trend.

It's observed a clear change in the precipitation patterns in the city of Belo Horizonte, reinforced by the fact that the increasing trend in the daily precipitation intensity (SDII) is associated with significant increases in the annual total precipitation (PRCPTOT), and the number of consecutive dry days over the year (CDD), which clearly indicates the increase in the events of intense rainfalls on the city.

The results from the abrupt changes tests are shown in Table 5. It can be observed that there are different years of change for the abrupt changes presented, eliminating the possibility of determining a single year of change which could be representative of changes in rainfall patterns of MRBH. This result was expected, since different trends were observed throughout the study.

Nevertheless, the station 01943055, which represents the city of Belo Horizonte, showed changes concentrated in the year of 1988 (highlighted in red in the Table 5), that in principle could 

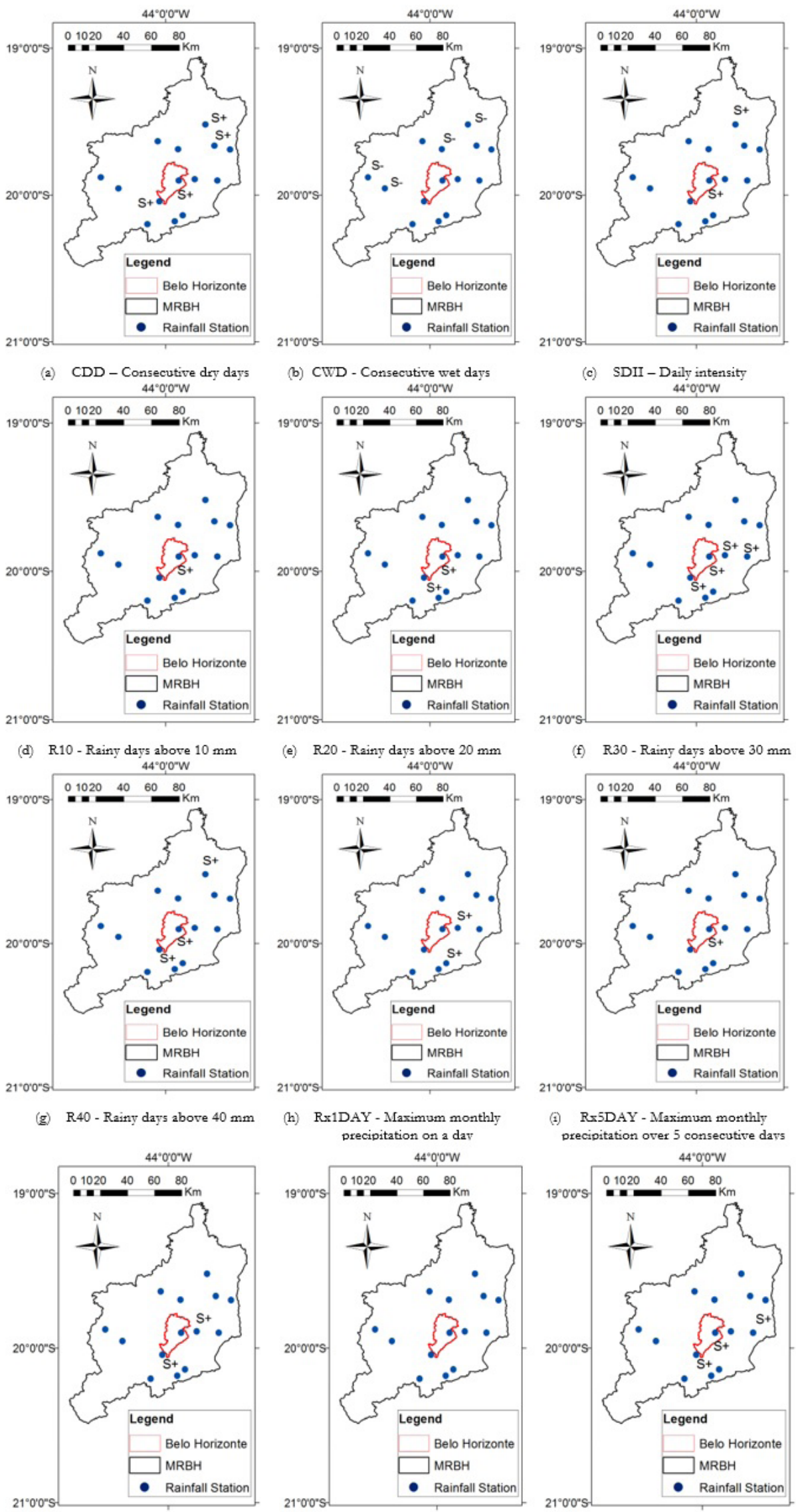

(h) Rx1DAY - Maximum monthly precipitation on a dav
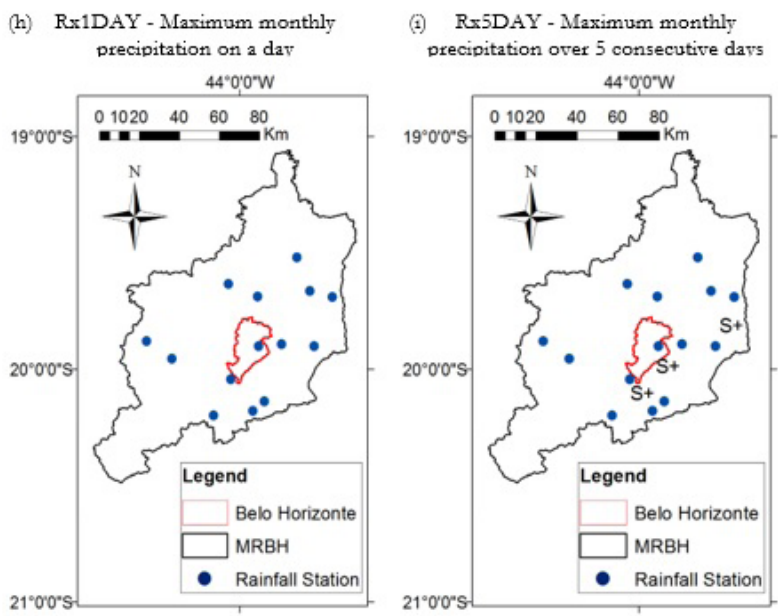

(j) R95P - Very wet days

(k) R99P - Extremely wet days

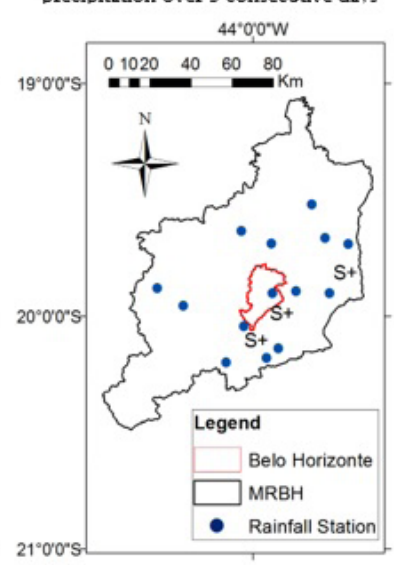

(1) PRCPTOT - Total annual wet days

Figure 5. Spatial distribution of the trends by precipitation index. 


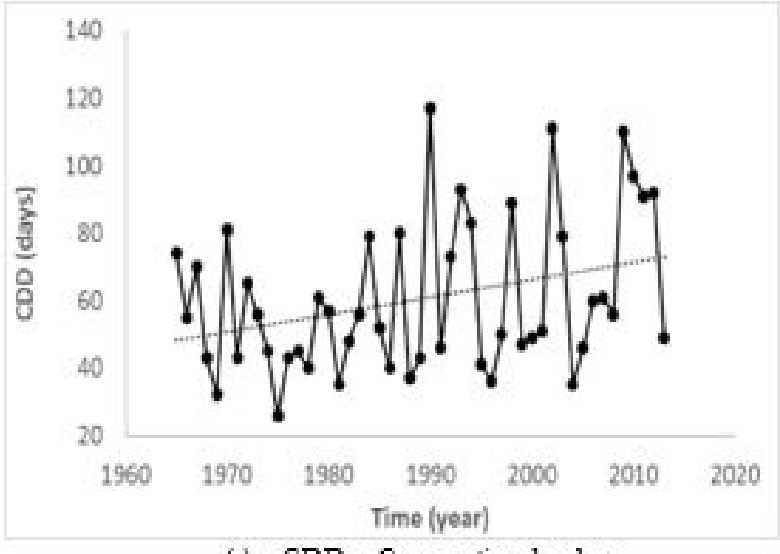

(a) CDD - Consecutive dry days

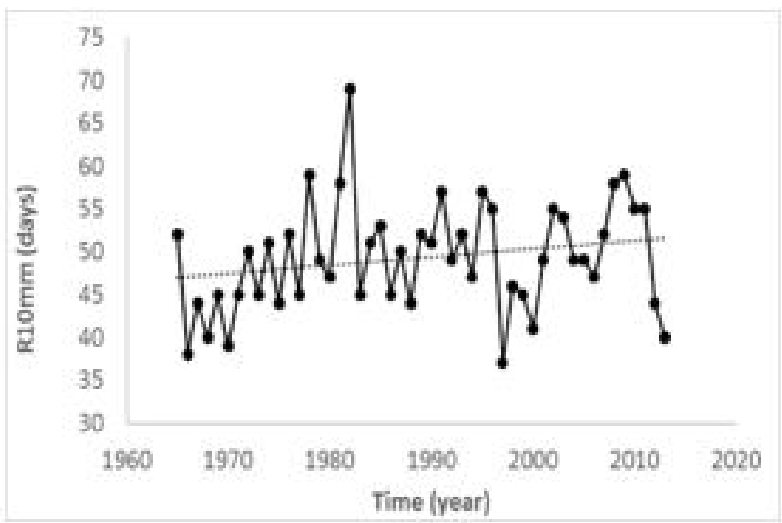

(c) R10 - Rainy days above $10 \mathrm{~mm}$

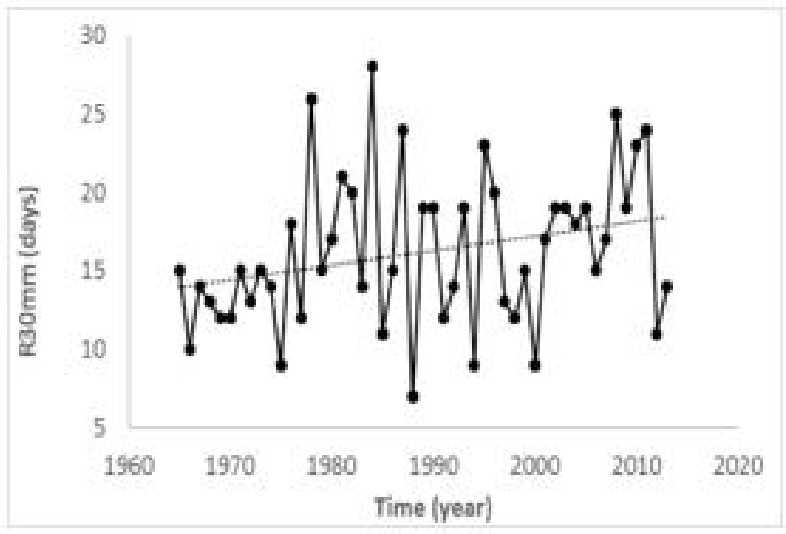

(e) Ra0 - Rainy days above $30 \mathrm{~mm}$

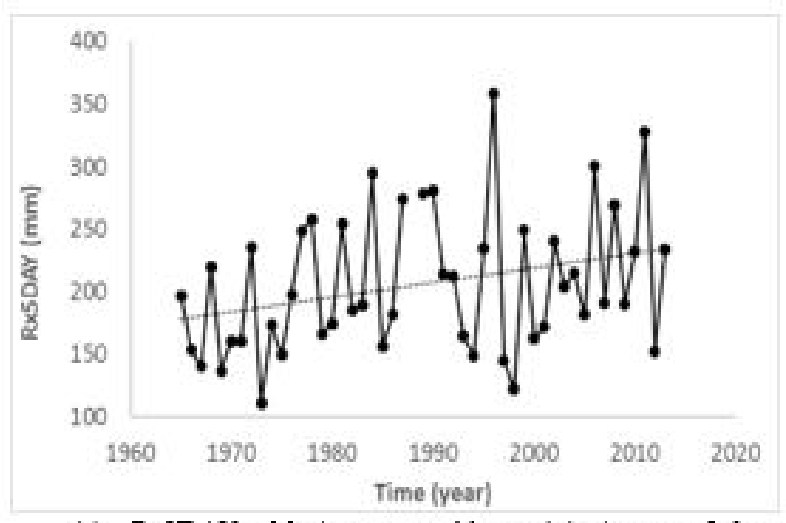

(g) Rx5DAY - Maximum monthly precipitztion over 5 dzys

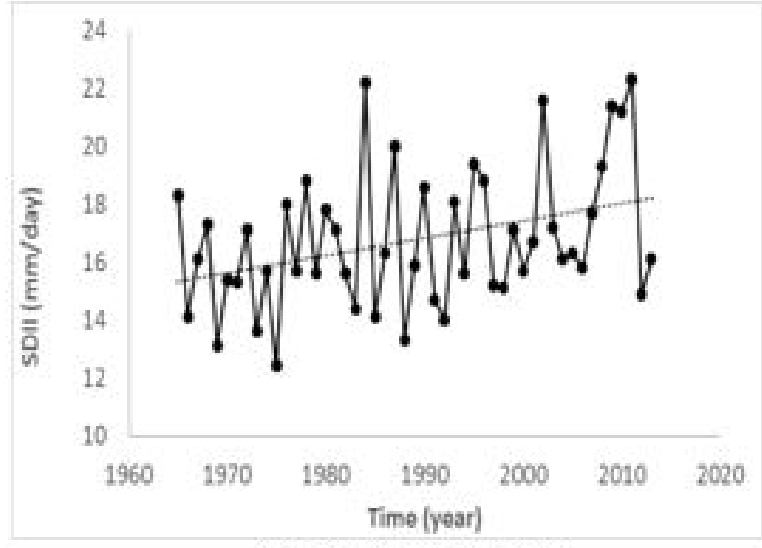

(b) SDII - Daily intensity

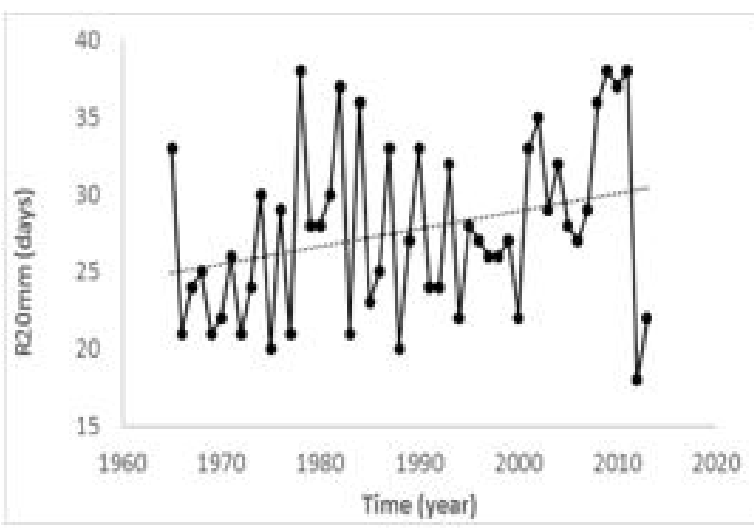

(d) R20 - Rainy days above $20 \mathrm{~mm}$

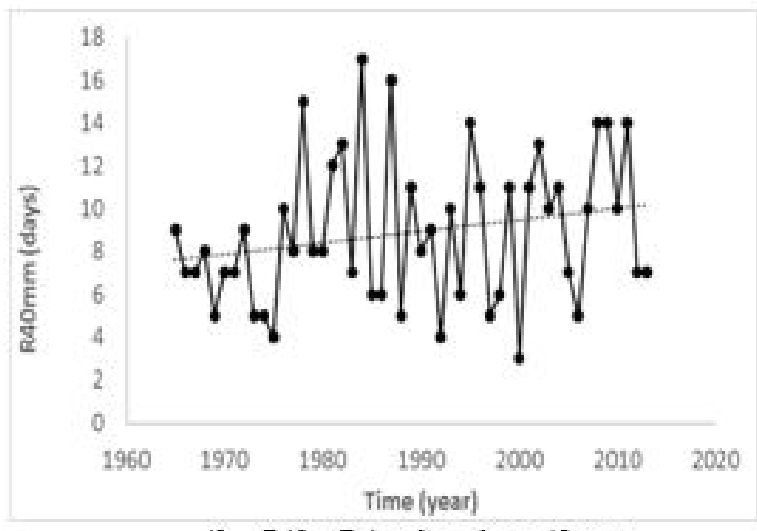

(f) R40 - Rainy daps zbove $40 \mathrm{~mm}$

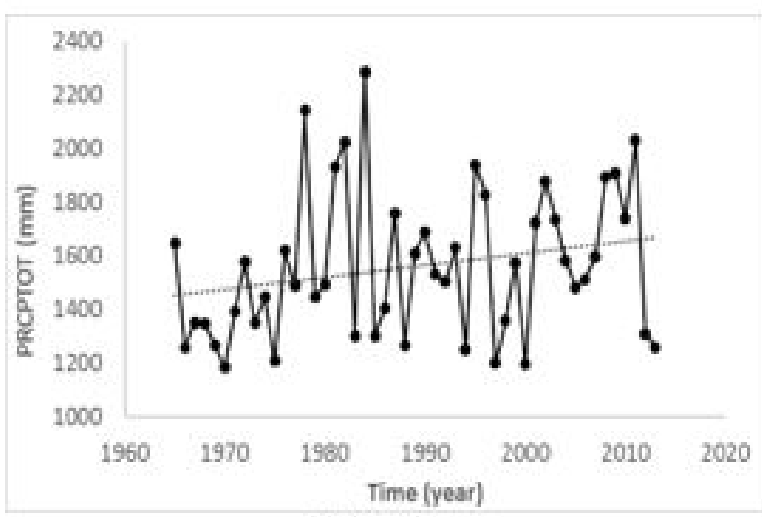

(h) PRCPTOT - Total zunuzl tret dzys

Figure 6. Temporal variation of the precipitation indices. 
Detection of trends for extreme events of precipitation in the Metropolitan Region of Belo Horizonte through statistical methods

Table 5. Results from the abrupt changes tests for precipitation considering the significance level of $5 \%$.

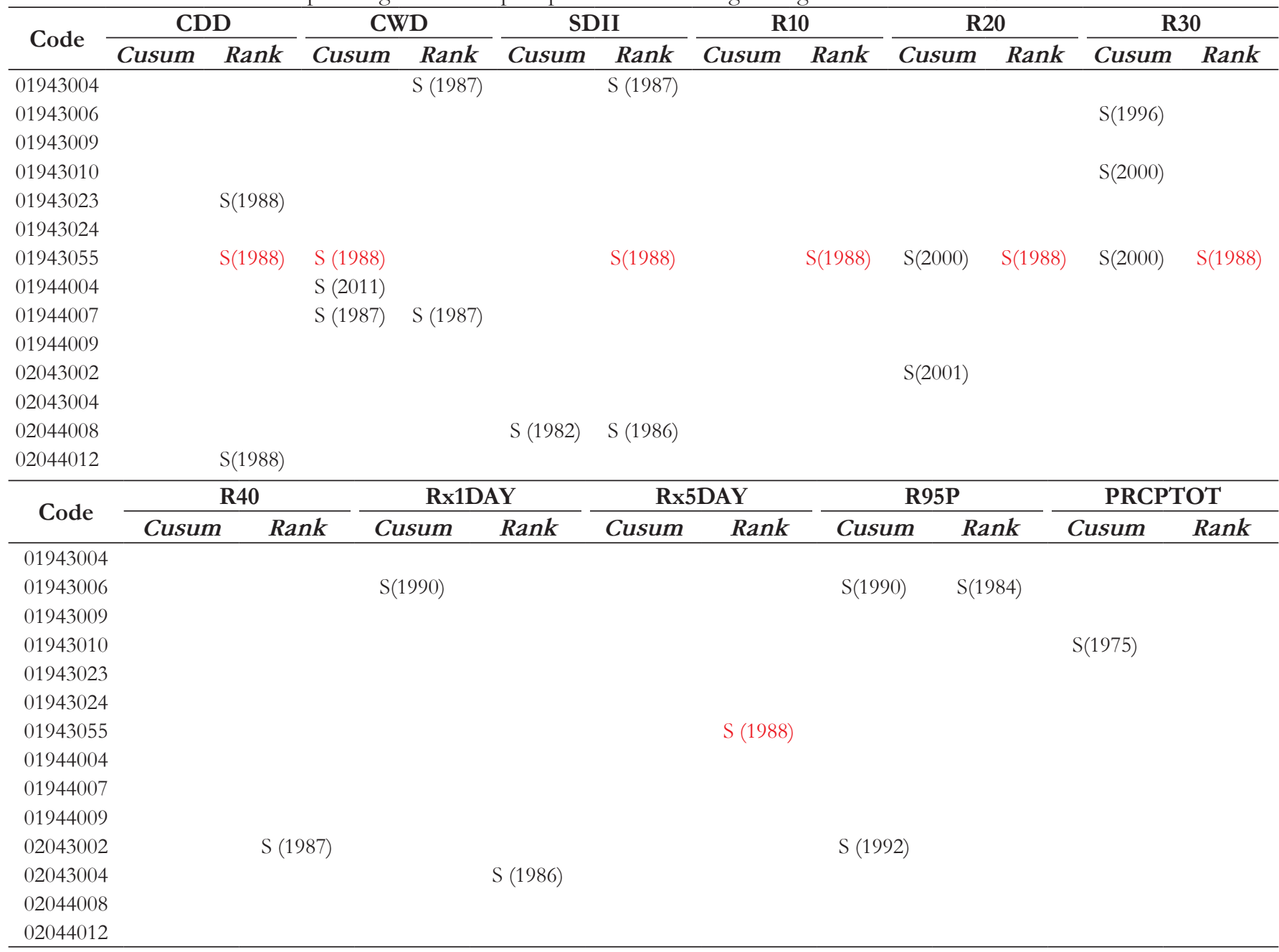

be a representative year of a significant urban expansion due to an intense migration to the MRBH.

Observing Figure 2 it is possible to notice that the city presented an expressive occupation process between the decades of 50 and 90 . However, although it could be thought that a trend evidenced from the year 1988 did not make sense for the city, in practice, even with the deceleration of the urban sprawl process, Belo Horizonte has been suffering with the process of verticalization of the city, being the 10th city with the greatest verticality of all Brazil (IBOPE, 2010).

In addition, it is worth mentioning that the consequences of the urban sprawl in the city were not evidenced exactly at the moment they occurred, since the city presented a significant development as a consequence of the strong immigration that occurred between the decades of 50 and 90 , i.e the city has been planned on demand. It is observed, for example, that from the 90 's many rivers of the city were channeled with the purpose of increasing the space for urban traffic.

The findings regarding existing trends and abrupt changes are only indications of possible changes in the climate pattern of the area. Despite the study of Alexandre, Baptista and Naghettini (2010), for the Metropolitan Region of Belo Horizonte, point to some trends of precipitation increase in the region, it analyzed only series of quarterly, semi-annual and annual precipitations.
From the surveys carried out, no studies were found that analyzed the frequency of occurrence of extreme precipitation events at stations in the region, based on daily data, and also have associated the results with temperature series.

\section{CONCLUSIONS}

The trend analysis for mean and minimum annual temperatures indicates a more pronounced positive trend for the Belo Horizonte station, when compared to the Florestal station (located in the RMBH), signaling to possible existence of an "urban heat island" in the Capital, where the rain gauge 01943055 is located.

Most indices showed significant trends in, at most, three stations in the MRBH, without a clear spatial pattern, and therefore had an inconclusive result at regional level. Nevertheless, the analysis of trends in R30 time series points to a positive trend in four rainfall stations, located in eastern part of the region.

Regarding the spatial distribution of the CWD, CDD and SDII indices, the results point to a trend to accumulate precipitations on a shorter time scale in the Northern and Central areas. However, no change was observed in PRCPTOT, indicating that extreme short-term precipitation events are more sensitive to changes in the environment when compared to annual precipitations. 
Regarding the station located in the city of Belo Horizonte, the identified trends indicated an increase in relevant indices related to urban draining systems. With regard to abrupt changes, it was observed a convergence of change in the year of 1988, so evidencing a representative year of a period of expressive urban expansion.

The findings regarding existing trends and abrupt changes are important to emphasize that the hypothesis of stationarity (the future will be statistically the same as the past) can not be confirmed. This type of information is essential to the decisionmaking process within the risk management perspective.

\section{ACKNOWLEDGEMENTS}

We acknowledge the National Council for Technological Development (CNPq), the Research Support Foundation of Minas Gerais State (FAPEMIG), the Coordination for the Improvement of Higher Education Personnel (CAPES) and the Research Incentive Fund of Puc Minas (FIP PUC Minas) for their financial support. We also thank the Superintendence of the Development of Belo Horizonte (SUDECAP) for providing some data used in the study.

\section{REFERENCES}

ALEXANDER, L. V.; ZHANG, X.; PETERSON, T. C.; CAESAR, J.; GLEASON, B.; KLEIN TANK, A. M. G.; HAYLOCK, M.; COLLINS, D.; TREWIN, B.; RAHIMZADEH, F.; TAGIPOUR, A.; RUPA KUMAR, K.; REVADEKAR, J.; GRIFFITHS, G.; VINCENT, L.; STEPHENSON, D. B.; BURN, J.; AGUILAR, E.; BRUNET, M.; TAYLOR, M.; NEW, M.; ZHAI, P.; RUSTICUCCI, M.; VAZQUEZ-AGUIRRE, J. L. Global observed changes in daily climate extremes of temperature and precipitation. Journal of Geophysical Research, v. 111, n. D5, p. 1-22, 2006. http://dx.doi. org/10.1029/2005JD006290.

ALEXANDRE, G. R.; BAPTISTA, M. B.; NAGHETTTINI, M. C. Estudo para identificação de tendências do regime pluvial na Região Metropolitana de Belo Horizonte a partir de métodos estatísticos. Revista Brasileira de Recursos Hídricos, v. 15, n. 2, p. 115126, 2010. http://dx.doi.org/10.21168/rbrh.v15n2.p115-126.

ANANIAS, D. S.; SOUZA, E. B.; SOUZA, P. F. S.; SOUZA, A. M. L.; VITORINO, M. I.; TEIXEIRA, G. M.; FERREIRA, D. B. S. Climatologia da estrutura vertical da atmosfera em novembro para Belém-PA. Revista Brasileira de Meteorologia, v. 25, n. 2, p. 218226, 2010. http://dx.doi.org/10.1590/S0102-77862010000200006.

ARAÚJO, E. D.; SILVA, J. B.; MACHADO, C. C. C. Identificação de ilhas de calor na cidade de Campina Grande-PB utilizando sensoriamento remoto. Revista Brasileira de Geografia Física, v. 9, n. 2, p. 614-626, 2016.

BAPTISTA, M.; NASCIMENTO, N.; BARRAUD, S. Técnicas compensatórias em drenagem urbana. $2^{\mathrm{a}}$ ed. Porto Alegre: ABRH, 2011. 318 p.
BLAIN, G. C.; PICOLI, M. C. A.; LULU, J. Análise estatística das tendências de elevação nas séries anuais de temperatura mínima do ar no estado de São Paulo. Bragantia, v. 68, n. 3, p. 807-815, 2009. http://dx.doi.org/10.1590/S0006-87052009000300030.

BLANCHET, J.; MOLINIÉ, G.; TOUATI, J. Spatial analysis of trend in extreme daily rainfall in southern France. Climate Dynamics, p. 1-14, 2016. http://dx.doi.org/10.1007/s00382-016-3122-7.

BRASIL. Ministério de Integração Nacional. Secretaria Nacional de Defesa Civil. Portaria Conjunta no. 148, de 18 de dezembro de 2013. Protocolo de Ações Integradas entre ANA, CEMADEN, CENAD e CPRM para emissão de alertas de inundação. Diário Oficial [da] República Federativa do Brasil, Brasília, DF, dez. 2013.

CHIEW, F.; SIRIWARDENA, L. Trend user guide. Australia: CRC for catchment hidrology. 2005. 29 p. Available from: <http://www. toolkit.net.au/tools/TREND/ documentation>. Access on: 23 apr 2015.

COTTON, W.; PIELKE, R. A. Sr. Human impacts on weather and climate. 2nd ed. Cambridge: Cambridge University Press, 2007. Chap 5.

DANTAS, L. G.; SANTOS, C. A. C.; OLINDA, R. A. Tendências anuais e sazonais nos extremos de temperatura do ar e precipitação em Campina Grande - PB. Revista Brasileira de Meteorologia, v. 30, n. 4, p. 423-434, 2015. http://dx.doi.org/10.1590/0102-778620130088.

FERREIRA, C. C. M.; BATISTA, G. M. F.; VIANNA, Y. C. G. Variações ou tendências climáticas: um estudo com as séries de temperatura do ar para a cidade de Juiz de Fora-MG. Revista de Ciências Humanas, v. 15, n. 2, p. 414-433, 2015.

HELSEL, D.; HIRSCH R. Statistical methods in water resources. Reston: US Geological Survey, Techniques of Water-Resources Investigations, 2002. Chap. A3, 522 p.

INSTITUTO BRASILEIRO DE GEOGRAFIA E ESTATÍSTICA - IBGE. Censo demográfico 2010. 2010. Available from: <http:// cidades.ibge.gov.br $/$ xtras $/$ perfil.php?codmun $=310620>$. Access on: 15 aug 2015.

INSTITUTO BRASILEIRO DE OPINIÃO E ESTATÍSTICA IBOPE. Mercado Imobiliário Residencial Brasileiro. 2010. Available from: <http://www.ibope.com.br/pt-br/noticias/Documents/110718_ Pyxis\%20Imobili\%C3\%A1rio.pdf>. Access on: 1 june 2017.

INTERGOVERNMENTAL PANEL ON CLIMATE CHANGE - IPCC. Summary for policymakers. In: FIELD, C. B.; BARROS, V.; STOCKER, T.F.; QIN, D.; DOKKEN, D. J.; EBI, K. L.; MASTRANDREA, M. D.; MACH, K. J.; PLATTNER, G.-K.; ALLEN, S. K.; TIGNOR, M.; MIDGLEY, P. M. (Eds.). Managing the risks of extreme events and disasters to advance climate change adaptation. Special report of working groups I and II of the Intergovernmental Panel on Climate Change. Cambridge: Cambridge University Press, 2012. p. 3-21. 
KISHTAWAL, C. M.; NIYOGI, D.; TEWARI, M.; PIELKE SRD, R. A.; SHEPHERDE, J. M. Urbanization signature in the observed heavy rainfall climatology over India. International Journal of Climatology, v. 30, n. 13, p. 1908-1916, 2009. http://dx.doi. org/10.1002/joc.2044.

KRISHNAKUMAR, K. N.; PRASADA RAO, G. S. L. H. V.; GOPAKUMAR, C. S. Rainfall trends in twentieth century over Kerala, India. Atmospheric Environment, v. 43, n. 11, p. 1940-1944, 2009. http://dx.doi.org/10.1016/j.atmosenv.2008.12.053.

KUNDZEWICZ, Z. W.; ROBSON, A. J. Change detection in hydrological records - a review of the methodology. Hydrological Sciences Journal, v. 49, n. 1, p. 7-19, 2004. http:/ /dx.doi.org/10.1623/ hysj.49.1.7.53993.

LEITÃO, M. M. V. B. R.; BEZERRA, P. T. C.; OLIVEIRA, G. M.; MENEZES, H. E. A.; PINTO, M. G. C. L. P. Expansão urbana e aumento da temperatura do ar nas cidades de Petrolina/ PE e Juazeiro/BA. In: SIMPÓSIO INTERNACIONAL DE ClimatologiA, 4., 2011, João Pessoa-PB. Anais... João Pessoa: IV SIC, 2011. p. 1-5.

MADSEN, H.; LAWRENCE, D.; LANG, M.; MARTINKOVA, M.; KJELDSEN, T. R. Review of trend analysis and climate change projections of extreme precipitation and floods in Europe. Journal of Hydrology, v. 519, p. 3634-3650, 2014. http://dx.doi. org/10.1016/j.jhydrol.2014.11.003.

MAGALHÃES FILHO, L. C. A.; ABREU, J. F. Ilha de calor urbana, metodologia para mensuração - Belo Horizonte, uma análise exploratória. Sistemas Cibernética e Informática, v. 12, n. 1, p. 1-6, 2015.

MOREIRA, J. G. V.; NAGHETTTINI, M. Detecção de tendências monotônicas temporais e relação com erros dos Tipos I e II: estudo de caso em séries de precipitações diárias máximas anuais do Estado do Acre. Revista Brasileira de Meteorologia, v. 31, n. 4, p. 394-402, 2016. http://dx.doi.org/10.1590/0102-778631231420140155.

MOURA, C. R. W.; ESCOBAR, G. C. J.; ANDRADE, K. M. Padrões de circulação em superfície e altitude associados a eventos de chuva intensa na Região Metropolitana do Rio de Janeiro. Revista Brasileira de Meteorologia, v. 28, n. 3, p. 267-280, 2013. http:/ /dx.doi. org/10.1590/S0102-77862013000300004.

NUNES, L. H. Repercussões globais, regionais e locais do aquecimento global. Terra Livre, v. 1, n. 20, p. 101-110, 2003.

PETERSON, T.C.; FOLLAND, C.; GRUZA, G.; HOGG, W.; MOKSSIT, A.; PLUMMER, N. Report of the Activities of the Working Group on Climate Change Detection and Related Rapporteurs. Geneva: World Meteorological Organization, 2001.146 p. (World Meteorological Organization Technical Document, 1071).

QUEIROZ, M. A. Avaliação de tendências em séries de precipitação diária máxima anual na faixa central do estado de Minas Gerais. 2013. 184 f. Dissertação (Mestrado em Saneamento, Meio Ambiente e Recursos Hídricos). Belo Horizonte: Universidade Federal de Minas Gerais, 2013.

RAIMUNDO, C. C.; SANSIGOLO, C. A.; MOLION, L. C. B. Tendências das classes de precipitação na Região Metropolitana de São Paulo. Revista Brasileira de Meteorologia, v. 29, n. 3, p. 397-408, 2014. http://dx.doi.org/10.1590/0102-778620130655.

REIS, R. J.; GUIMARÃES, D. P.; COELHO, C. W. G. A.; PAIXÃO, G. M.; NASCIMENTO, J. S.; SIMÕES, T. K. S. L. Determinação das áreas de potencial de riscos de precipitações intensas em Belo Horizonte. Caderno de Geografia, v. 14, n. 23, p. 127-134, 2004.

SALVIANO, M. F.; GROPPO, J. D.; PELLEGRINO, G. Q. Análise de tendências em dados de precipitação e temperatura no Brasil. Revista Brasileira de Meteorologia, v. 31, n. 1, p. 64-73, 2016. http:// dx.doi.org/10.1590/0102-778620150003.

SANCHES, F. O.; VERDUM, R.; FISCH, G. Estudo de tendência de chuvas de longo prazo. Ambiente \& Água, v. 8, n. 3, p. 214228, 2013.

SANTOS, C. A.; LIMA, A. M. M.; FARIAS, M. H. C. S.; AIRES, U. R. V.; SERRÃO, E. A. O. Análise estatística da não estacionariedade de séries temporais de vazão máxima anual diária na bacia hidrográfica do rio Pardo. Holos, v. 7, p. 179-193, 2016. http://dx.doi.org/10.15628/holos.2016.4892.

SEN ROY, S.; BALLING JR, R. C. Trends in extreme daily precipitation indices in India. International Journal of Climatology, v. 24, n. 4, p. 457-466, 2004. http://dx.doi.org/10.1002/joc.995.

SHANG, H.; YAN, J.; GEBREMICHAEL, M.; AYALEW, S. M. Trend analysis of extreme precipitation in the northwestern highlands of Ethiopia with a case study of debre markos. Hydrology and Earth System Sciences, v. 15, n. 6, p. 1937-1944, 2011. http:// dx.doi.org/10.5194/hess-15-1937-2011.

SHAW, R.; SHARMA, A. Beyond resilience mapping. In: SHAW, R. Climate and disaster resilience in cities (Community, Environment and Disaster Risk Management). Bingley: Emerald Group Publishing Limited, 2011. v. 6, p. 281-287.

SIGRIST, F.; KÜNSCH, H. R.; STAHEL, W. A dynamic nonstationary spatio-temporal model for short term prediction of precipitation. The Annals of Applied Statistics, v. 6, n. 4, p. 1452-1477, 2012. http:/ /dx.doi.org/10.1214/12-AOAS564.

SILVEIRA, R. N. P. O.; FERNANDES, L. L.; SILVA, M. N. A. Tendência de precipitações pluviométricas e avaliação da influência dos ENOS no distrito de Abunã, Rondônia. Revista Brasileira de Gestão Ambiental, v. 1, n. 11, p. 14-20, 2017.

SOUZA, D. O.; NASCIMENTO, M. G.; ALVALÁ, R. C. S. Influência do crescimento urbano sobre o microclima de Manaus e Belém: um estudo observacional. Revista Brasileira de Geografia Física, v. 8, n. 4, 2015, p. 1109-1124. 
TSONIS, A. A. Widespread increases in low-frequency variability of precipitation over the past century. Nature, v. 382, n. 6593, p. 700-702, 1996. http://dx.doi.org/10.1038/382700a0.

VAN DEN BESSALAR, E. J. M.; KLEN-TANK, A. M. G.; BUISHAND, T. A. Trends in European precipitation extremes over 1951-2010. International Journal of Climatology, v. 33, p. 26822689, 2013.

VILLARINI, G.; SMITH, J. A.; BAECK, M. L.; VITOLO, R.; STEPHENSON, D. B.; KRAJEWSKI, W. F. On the frequency of heavy rainfall for the Midwest of the United States. Journal of Hydrology, v. 400, n. 1-2, p. 103-120, 2011. http://dx.doi. org/10.1016/j.jhydrol.2011.01.027.

WANDERLEY, H. S.; SEDIYAMA, G. C.; JUSTINO, F. B.; ALENCAR, L. P.; DELGADO, R. C. Variabilidade da precipitação no Sertão do São Francisco, estado de Alagoas. Revista Brasileira de Engenharia Agricola e Ambiental, v. 17, n. 7, p. 790-795, 2013. http:/ / dx.doi.org/10.1590/S1415-43662013000700014.

WILLETT, K. M.; JONES, P. D.; GILLET'T, N. P.; THORNE, P. W. Recent changes in surface humidity: development of the HadCRUH dataset. Journal of Climate, v. 21, p. 5364-5383, 2008.

WMO - WORLD METEOROLOGICAL ORGANIZATION. Guidelines on analysis of extremes in a changing climate in support of informed decisions for adaptation. Geneva, 2009. No. 1500.
WMO - WORLD METEOROLOGICAL ORGANIZATION. The role of climatological normals in a changing climate. Geneva, 2007. WCDMP-No. 61, WMO-TD/No. 1377.

XAVIER, T. M. B. S. Tempo de chuva: estudos climáticos e de previsão para o Ceará e Nordeste Setentrional. Fortaleza: ABC Editora, 2001. 478 p.

XU,Z.X.;ZHANG, L.; RUAN, B. Q. Analysis on the spatiotemporal distribution of precipitation in the Beijing Region. Arid Land Geography, v. 29, n. 2, p. 186-193, 2006.

YANG, P.; WANG, G.; BIAN, J.; ZHOU, X. The prediction of nonstationary climate series based on empirical mode decomposition. Advances in Atmospheric Sciences, v. 27, n. 4, p. 845-854, 2010. http:/ / dx.doi.org/10.1007/s00376-009-9128-x.

\section{Authors contributions}

Aline de Araújo Nunes: First author who contributed to literature review, methodology proposal, analysis and discussion of results, as well as writing and formatting of the article.

Éber José de Andrade Pinto: Co-advisor on research who contributed to the methodology, discussion of the results and final review.

Márcio Benedito Baptista: Principal advisor who contributed to the methodology, discussion of the results, and revision of the article. 